\title{
Tectonic wedge escape in the southwestern front of the Rif Cordillera (Morocco)
}

\author{
A. CHALOUAN ${ }^{1}$, J. GALINDO-ZALDÍVAR ${ }^{2}$, M. AKIL ${ }^{1}$, C. MARÍN ${ }^{3}$, A. CHABLI ${ }^{1}$, \\ P. RUANO $^{4}, \mathrm{~K}_{\text {BARGACH }}{ }^{1}$, C. SANZ DE GALDEANO ${ }^{5}$, M. BENMAKHLOUF ${ }^{2,6}$, \\ M. AHMAMOU ${ }^{1} \&$ L. GOURARI ${ }^{7}$
}

${ }^{1}$ Département des Sciences de la Terre, Faculté des Sciences, Université Mohammed V-Agdal, BP 1014, Rabat, Morocco (e-mail: chalouan@fsr.ac.ma)

${ }^{2}$ Departamento de Geodinámica, Universidad de Granada, 18071, Granada, Spain

${ }^{3}$ Instituto Geológico y Minero de España, Río Rosas 23, 28003 Madrid, Spain

${ }^{4}$ Institute for Crustal Studies, University of California, Santa Barbara, CA 93106-1100, USA

${ }^{5}$ Instituto Andaluz de Ciencias de la Tierra, CSIC-Universidad de Granada, 18071, Granada, Spain

${ }^{6}$ Département de Géologie, Faculté des Sciences de Tétouan, Université Abdelmalek Essaadi, Tétouan, Morocco

${ }^{7}$ Département de Géologie, Faculté des Sciences Dhar el-Mashraz, Université Sidi Mohamed Ben Abdellah, Fès, Morocco

\begin{abstract}
The Rif Cordillera is a part of the Alpine orogenic arc in the Western Mediterranean, which was developed by the interaction of the westward motion of the Alboran Domain between the converging Eurasian and African plates. The Prerif Ridges, located along the southwestern front of the Rif, are south-vergent folds that are in places associated with faults affecting Jurassic to Quaternary sedimentary rocks and slope breccias that evidence the deformations that were active over the Neogene-Quaternary period. The different southward or southwestward displacement of each Prerif Ridge is related to the development of frontal and lateral ramps, which may or may not reach the surface. Oblique shortening may be explained by southwestward escape of large tectonic wedges, bounded by large strike-slip faults: the North-Middle Atlas fault which extends northward into the Alboran Sea, the Fez-Tissa-Taïneste fault, the Bou Draa-Sidi Fili fault, the Jebha fault and the Fahies fault. The relative displacement of these tectonic wedges toward the SW may explain the NNE-SSW to ENE-WSW compression observed in the Rif front and in the northern part of its Meseta-Atlas foreland.
\end{abstract}

The Betic-Rif Cordilleras developed in the Western Mediterranean as a consequence of the relative motion of the African and Eurasian plates, with a recent NW-SE convergence of $4 \mathrm{~mm} \mathrm{a}^{-1}$ (De Mets et al. 1990). The western part of these cordilleras forms an arc produced by the westward motion of the relatively rigid Alboran Domain, located in the internal part of the tectonic arc, between the two plates (Fig. 1). The Alboran Domain (García-Dueñas \& Balanyá 1986) is an independent tectonic element formely known as the 'Alboran microplate' (Andrieux et al. 1971), which at present is undergoing internal deformation. Changes of the relative motion of the three main tectonic plates are reflected by overprinted deformations, well recorded in the Rif Cordillera, and in particular in its frontal part
(Frizon de Lamotte et al. 2000; Chalouan et al. 2001) and by the development of the arcuate belt (Platt et al. 2003).

The front of the Rif Cordillera includes the External Prerif (the 'Nappe Prérifaine') and the overthrusting Rif thrust sheets, which crop out towards the inner part of the Cordillera (Fig. 2). The age of the main deformations responsible for the thrust sheet emplacement in this region is younger towards the front, starting from the Late Miocene (TortonianMessinian), with the displacement of the Rif over its Meseta-Atlas foreland, and the development of thrusts in the frontal part of the Prerif Ridges. In addition, the Prerif Ridges have undergone a late deformation (Miocene-present) that affected the sediments of the Neogene-Quaternary basins, between the Rif and the foreland (Feinberg 1986; 


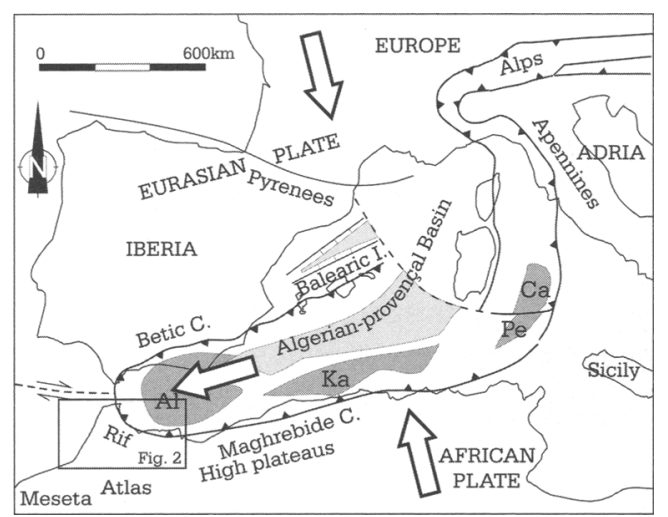

Fig. 1. Main tectonic elements in the Western Mediterranean since the Early Miocene. Dark grey, Alkapeca derived terranes: Al, Alboran; Ka, Kabylias; Pe, Peloritani; Ca, Calabria. Light grey, deep basins.

Samaka et al. 1997). These regional deformations are associated with an anticlockwise rotation of the trend of compression (Morel 1988; Ait Brahim 1991). Whereas the Tortonian deformations are related to a NE-SW-oriented compression, the Messinian ones are related to a north-south-trending compression, which, during the Pliocene and the Quaternary, rotated to NNW-SSE, in agreement with the trend of the recent convergence between the African and Eurasian plates.

In this framework, the lateral escape tectonics may be a process of great importance during the development of the cordillera. According to Royden (1993), escape tectonics may occur in a direction oblique or orthogonal to the plate convergence in zones of relatively thin continental crust. In this framework, escape tectonics may develop from an initial stage involving subduction with trench retreat (rollback subduction).

The aim of this paper is to analyse the compressional and extensional deformations of the southwestern part of the Rif mountain front (External Prerif) represented by the Prerif Ridges' folds and thrusts, the Plio-Quaternary sediments deposited in the foreland basin (Saïss Basin) and the foreland basement formed by the northern Meseta and Middle Atlas. The recent tectonic structures that affect rocks of Pliocene to Quaternary age show evidence of variable trends of compression (NNW-SSE, north-south and NE-SW) related to the activity of major crustal faults. These data lead us to propose the southwestward lateral escape of tectonic wedges bounded by crustal transcurrent and thrust faults in the Rif Cordillera. The deformation of its frontal part in a skin tectonic model is a consequence of the interaction of the minor blocks located between the Eurasian and African plates.

\section{Geological and tectonic setting}

The development of the Rif Cordillera is the consequence of the overprinting of several Alpine deformations, sometimes on Variscan structures, affecting its Internal and external zones to a different extent. Whereas the internal zone of the Rif Cordillera is formed by Palaeozoic and Mesozoic sequences that are partially affected by Alpine metamorphism, the external zone is made up of Mesozoic and Cenozoic sedimentary rocks including calcareous and marly series. From the inner to the outer parts of the External Rif, three tectonic areas are differentiated: the Intrarif, the Mesorif and the Prerif zones (Fig. 2). Between the internal and external zones, flysch nappes overthrusting the Neogene metamorphic rocks of the Ketama unit crop out.

The internal zone, comprising the Sebtide and Ghomaride metamorphic complexes, underwent the main Alpine deformation during the EoceneLate Oligocene (Kornprobst 1974; Chalouan et al. 2000, 2001, 2003; Chalouan \& Michard 2004). The ductile and brittle deformations that developed during this stage mainly consist of folds and thrusts, with main north-south to NNW-SSE trends and a west to SW vergence. In the Sebtide units, the metamorphism related to these deformations reaches blueschist and eclogite facies (Goffé et al. 1997; Bouybaouene et al. 1998), confirming that HP/LT metamorphic conditions were attained in a subduction zone (Chalouan et al. 2001, 2003).

The external zone, located south of the Jebha fault zone (Fig. 2), underwent main Alpine deformations mostly during the Late Tortonian. These deformations developed east-west-oriented structures including folds, thrusts and foliation. However, these structures locally show a northsouth preferred orientation: (1) along the western Mesorif, where Ben Yaïch (1991) described westvergent folds and thrusts that deform the Mesorif and Intrarif units of Loukkos and external Tangier; (2) in the Ouezzane thrust sheets, located north, west and south of Ouezzane (Fig. 2), where Tejera de León $(1993,1997)$ described thrusts and folds that deform Eocene to middle Miocene rocks; (3) along the Habt thrust sheet and the Intrarif in the region of Ksar El Kebir-Arbaoua; this region was studied by Zakir (2004) and Zakir et al. (2004), who noted the presence of ramps and accommodation folds.

The foreland cover involved in the Rif frontal thrust deformations, and that constitutes the Prerif Ridges, is affected by thrusts and foldrelated faults of east-west (Zarhoun, Trhatt and Zalagh), NW-SE (Kefs and Kannoufa), northsouth (Tselfat and Outita) and NE-SW (Bou Draa) orientations, forming two large arched structures (Fig. 3). 


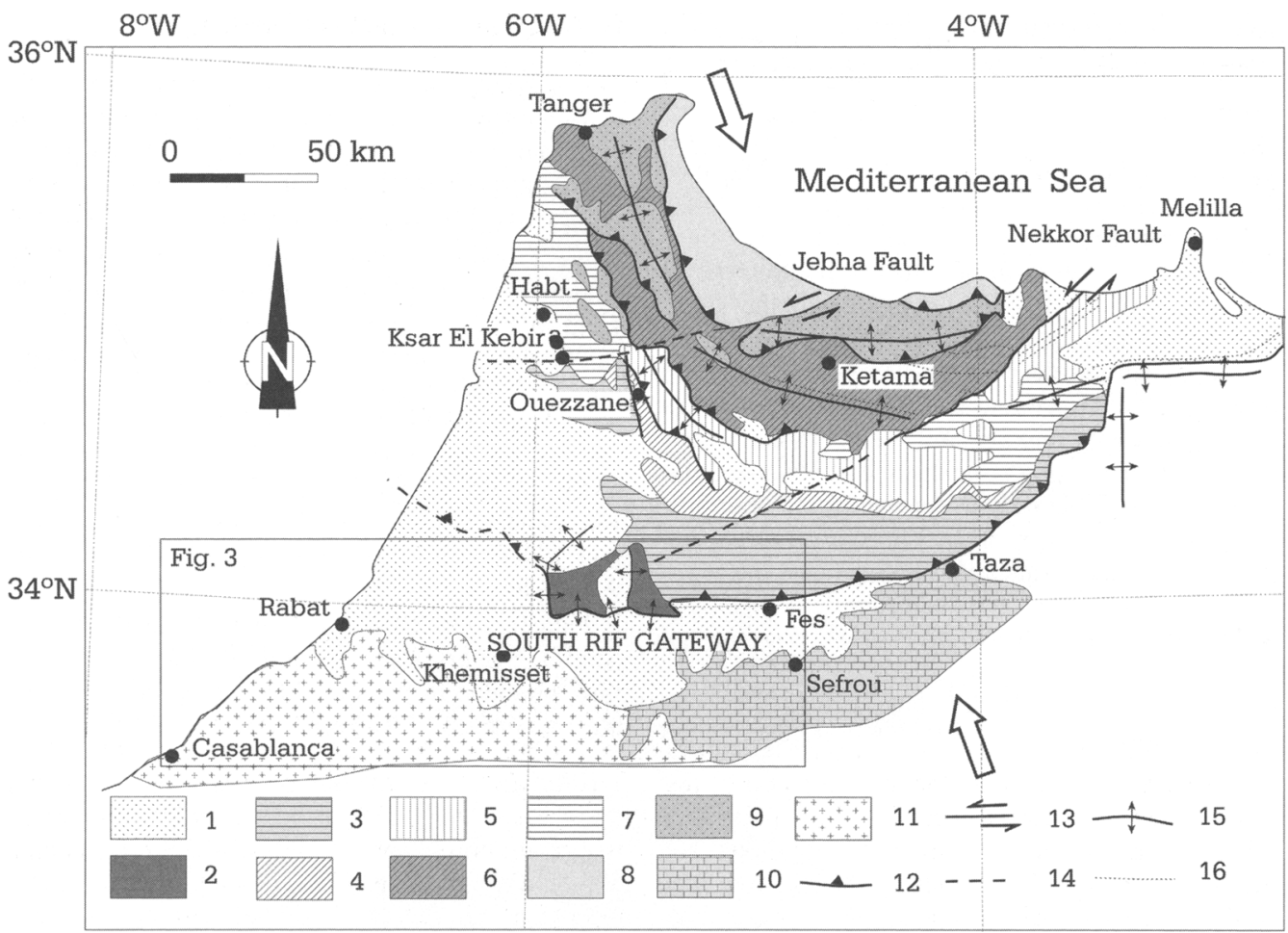

Fig. 2. Main Alpine structures of the Rif Cordillera. 1, Saïss-Gharb-Maamoura Neogene foreland basins; 2, Prerif Ridges; 3, External Prerif (Prerif Nappe and Rifian Ouezzane thrust sheets); 4, Internal Prerif; 5, Mesorif; 6,

Intrarif (Ketama metamorphic unit and Tangiers-Loukkos unit); 7, Rifian thrust sheets; 8, internal zones; 9, flysch nappes; 10, Middle Atlas; 11, Meseta; 12, thrust; 13, strike-slip fault; 14, supposed fault; 15, large antiform; 16, fold trace orientation.

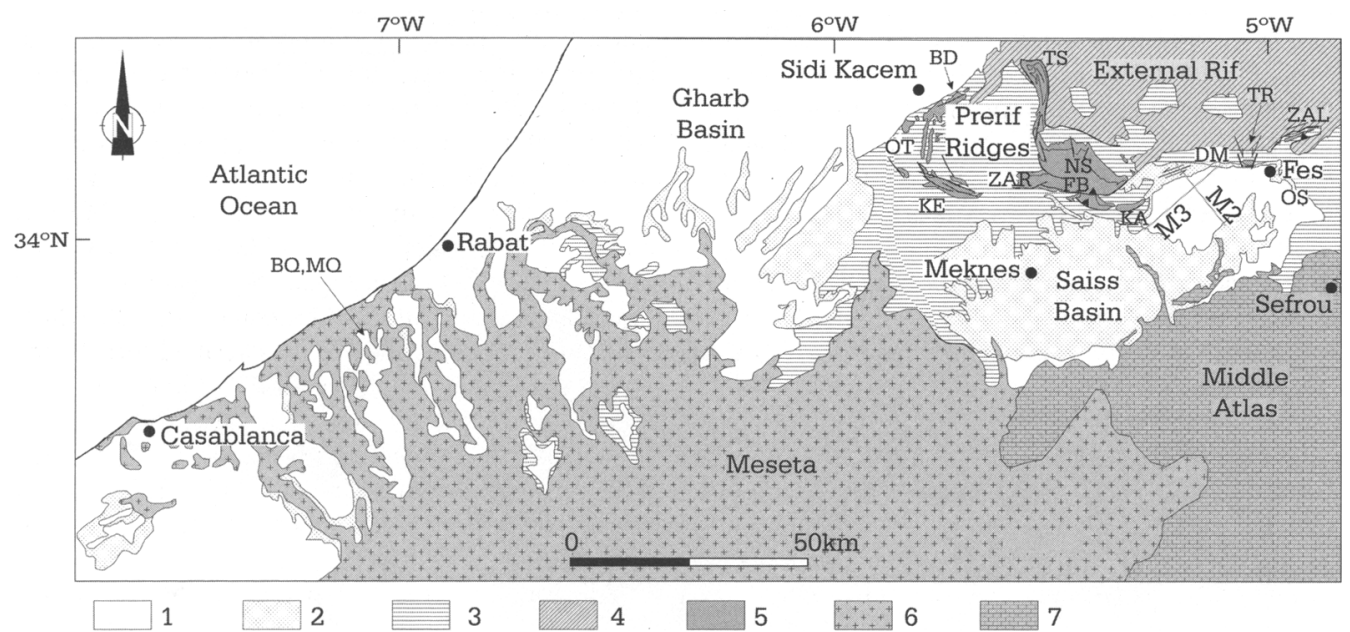

Fig. 3. Geological sketch of the southwestern Rif front and its Meseta-Atlas foreland. 1, Quaternary sediments; 2 , Pliocene marine and lacustrine sediments of Saïss Basin; 3, Upper Miocene rocks; 4, External Prerif (Prerif Nappe and Rifian Ouezzane thrust sheets); 5, Prerif ridges; 6, Meseta foreland; 7, Middle Atlas foreland. BD, Bou Draa ridge; BQ, Brahma quarry; DM, Draa el Merga; FB, Fert el Bir ridge; KA, Kannoufa ridge; KE, Kefs ridge; MQ, Mjeddba quarry; NS, Dehar en Nsour ridge; OS, Oued Sebou; OT, Outita ridge; TR, Trhatt ridge; TS, Tselfat ridge; ZAL, Zalagh ridge; ZAR, Zarhoun ridge. 


\section{Recent compressional deformations in the Rif front and in its Meseta-Middle Atlas foreland}

The analysed sectors are located along: the front of the Prerif (External Prerif or Prerif Nappe) (Figs 2 and 3); the Prerif Ridges, and particularly their southern and western fronts; the northern border of the South Rif gateway, in particular the Saîss Basin; the Atlas foreland in the Sefrou region; and the Mesetian foreland in the Casablanca region (Fig. 3). The determination of palaeostresses has been done taking into account the major and minor faults measured along large distances. Detailed analyses were possible only in some selected outcrops, such as the Jbel Trhatt or the Plio-Quaternary quarries between Casablanca and Rabat.

\section{Rif front and Prerif Ridges}

Jbel Zalagh, located NE of Fez (Fig. 4), is an ENEWSW-trending narrow elongated Prerif ridge, formed by Jurassic and Tertiary rocks cropping out along an antiform. The Jurassic formations consist, from bottom to top, of $200-300 \mathrm{~m}$ of Lower Liassic crystalline, massive dolostones (Faugères 1978), Middle Liassic well-stratified limestones $(60-100 \mathrm{~m})$ overlain by marly limestones with chert $(15 \mathrm{~m})$, and finally marls with intercalations of limestone $(60 \mathrm{~m})$ of Late Liassic-Dogger age. The Tertiary formations are, from bottom to top, molasse formed by marly sands and conglomerate, white marls unconformably overlying the molasse and locally lying on the Jurassic rocks, the complex Prerif Nappe, Messinian marls that appear locally on the southern side close to Aïn Laaleg (Wernli 1988), and finally a Plio-Quaternary conglomeratic formation on top that is sometimes unconformable on the Jurassic Zalagh limestones.

Faugères (1978) considered Jbel Zalagh to be a southward very steeply dipping monoclinal structure, bounded to the south and to the north by two almost vertical $\mathrm{N} 70^{\circ} \mathrm{E}$-oriented faults. The northern
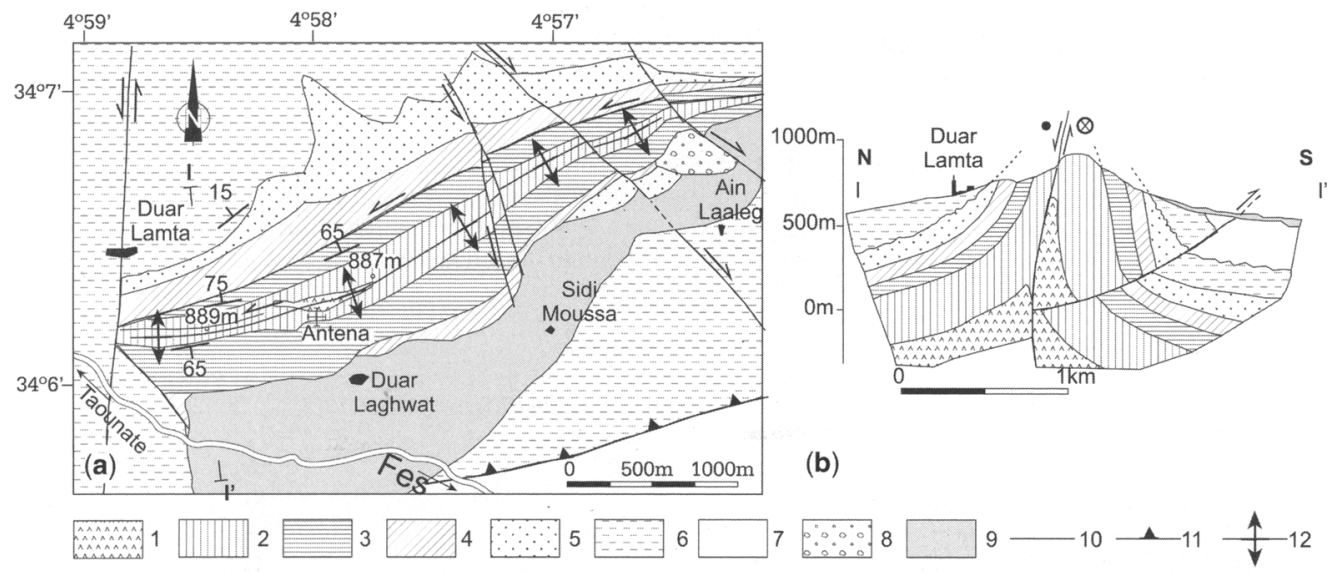

(b)

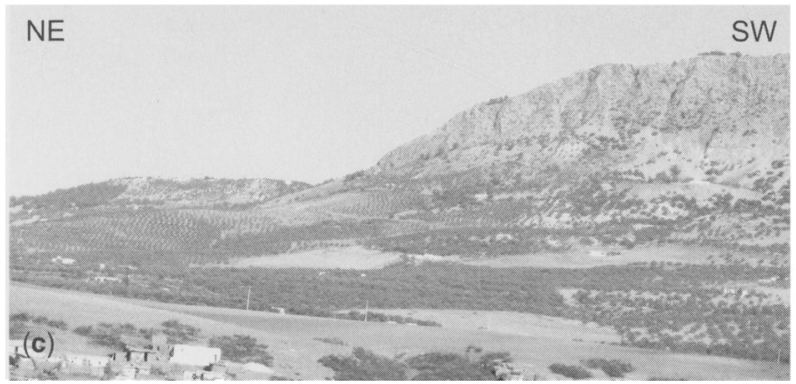

(d)

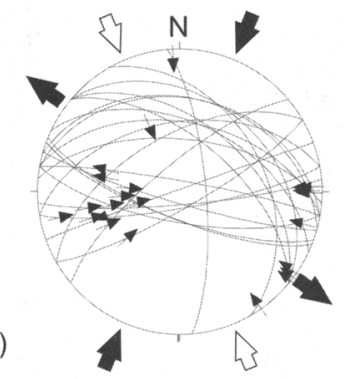

Fig. 4. Jbel Zalagh. Geological map (a) and cross-section (b). 1, Triassic rocks; 2, lower Liassic dolostones; 3, middle Liassic limestones; 4, upper Liassic-Bajocian marls and limestones; 5, upper Miocene molasse; 6, upper Miocene marls; 7, upper Miocene Prerif Nappe; 8, Quaternary slope breccias; 9, Quaternary sediments; 10, fault; 11, thrust; 12, anticline. (c) View of fault scarp in the northern limb of Zalagh ridge. (d) Stresses and measured microfaults, equal area projection, lower hemisphere. Black arrows, oldest stresses; white arrows, youngest stresses. 
fault has been considered by Moratti et al. (2003) as an active fault related to a NNE-SSW compression that produced a sharp scarp (Fig. 4c), affecting recent deposits, and responsible for the seismic activity of the region. Structural analysis of this sector shows that Jbel Zalagh is, rather, a close to tight and faulted fold (Fig. 4). The southern limb of the fold occupies the whole southern side of the crest, and partially its summit. The hinge of the fold appears only toward the summit. The northern limb of the fold appears in the central and eastern part of the northern side of the crest. On the other hand, this limb is partially absent in the western region as a result of the $\mathrm{N} 70^{\circ} \mathrm{E}$-fault located along the fold (Fig. 4). In addition, the Jbel Zalagh anticline is affected by ENE-WSW south-verging reverse faults and by NW-SE dextral faults, mainly in the eastern extremity. The reverse faults could be interpreted as frontal ramps that formed simultaneously with the main fold in a NNW-SSE compressional deformation.

The two main fault sets recognized in the region show evidence of recent activity. The $\mathrm{N} 70^{\circ} \mathrm{E}$ fault of the northern side has a high dip $\left(70^{\circ}-80^{\circ}\right.$ north or south) and a main horizontal sinistral slip with a minor vertical component that downthrows the northern block. This fault is of Quaternary age (Moratti et al. 2003), and has been active after the development of the fold. The $\mathrm{N} 170^{\circ} \mathrm{E}-\mathrm{N} 30^{\circ} \mathrm{E}$ sinistral and $\mathrm{N} 135^{\circ} \mathrm{E}-150^{\circ} \mathrm{E}$ dextral faults are even more recent, as they affect the $N 70^{\circ} \mathrm{E}$ fault and show Quaternary slope deposits on the southern side of Jbel Zalagh. Microtectonic analysis of these faults suggests that the trend of the maximum compressional axis $\left(\sigma_{1}\right)$ responsible for the oldest $\mathrm{N} 70^{\circ} \mathrm{E}$ fault was NNE-SSW, whereas the second stage, responsible for the strike-slip transversal faults, was a NW-SE-oriented compression (Fig. 4).

Jbel Trhatt, located west of Fez, is an east-westtrending anticline resulting from a recent northsouth shortening, affecting Jurassic and Miocene series (Fig. 5). Its structure has similarities to that of Jbel Zalagh, but without outcrops of the lower-Middle Liassic series, which are known only from boreholes (Faugères 1978). In the
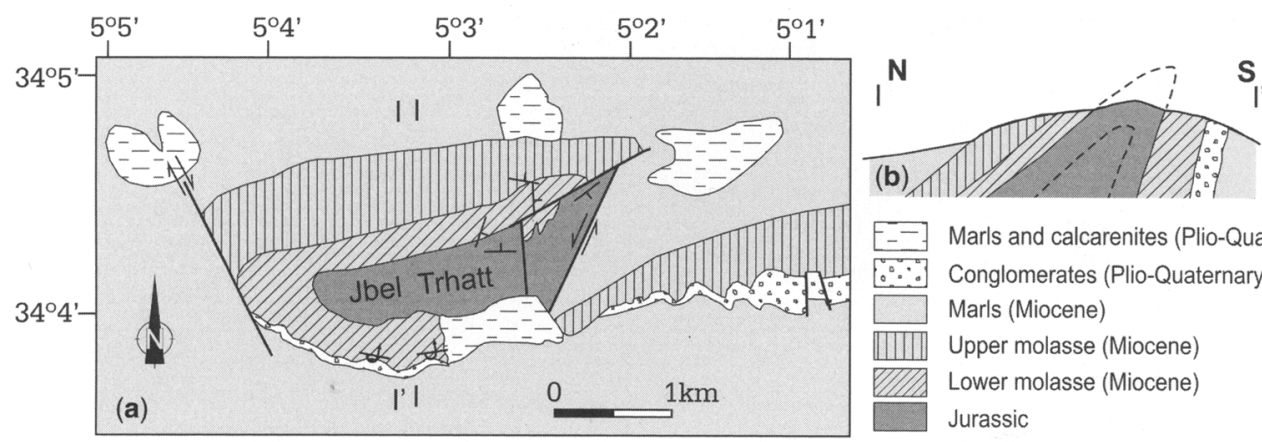

Marls and calcarenites (Plio-Quaternar Conglomerates (Plio-Quaternary) Marls (Miocene)

Upper molasse (Miocene)

Lower molasse (Miocene)

Jurassic
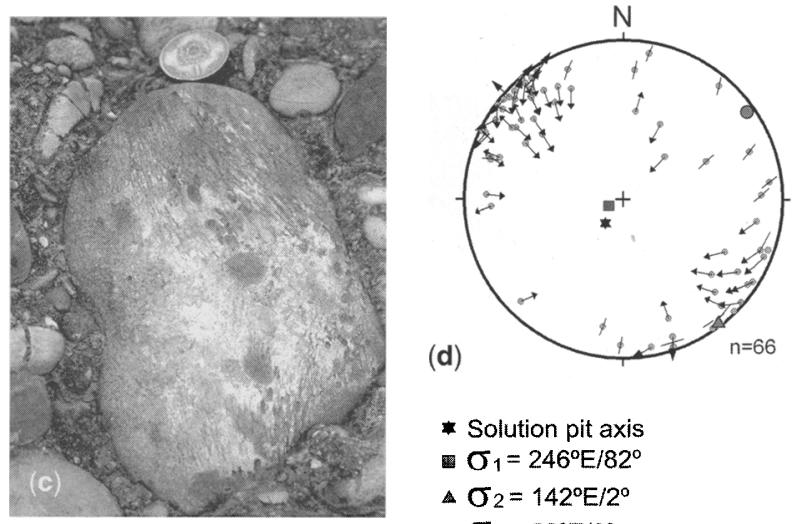

(e)

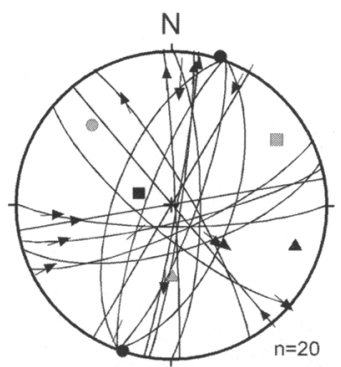
* Solution pit axis
‥ $\sigma_{1}=246^{\circ} \mathrm{E} / 82^{\circ}$
$\triangle \sigma_{2}=142^{\circ} \mathrm{E} / 2^{\circ}$
- $\sigma_{3}=52^{\circ} \mathrm{E} / 8^{\circ}$ $\mathrm{R}=0.1$

Fig. 5. Jbel Trhatt. Geological map (a) and cross-section (b). (c) Field view of striated pebbles. (d) Palaeostress determination from striated pebbles. (e) Palaeostress determination from microfaults, lower hemisphere, equal area projection. $n$, number of data; $R$ (axial ratio) $=\left[\left(\sigma_{2}-\sigma_{3}\right) /\left(\sigma_{1}-\sigma_{3}\right)\right]$. 
southern limb of this south-verging anticline, almost vertical or overturned Plio-Quaternary conglomerates, marls and limestones overlie the previous series with a low-angle unconformity. The conglomerate mainly consists of rounded calcareous pebbles. Analysis of striations and solution pits in pebbles from the southern part of Jbel Trhatt reveals, for each studied pebble, two or three palaeo-states of stress, with a main subvertical compressional axis (Fig. 5) (Bargach et al. 2004; Ruano et al. 2006), or northward-inclined axes, which, when folding is restored, point to a north-south-trending shortening. The Jbel Trhatt anticline is bounded to the west by a NW-SE dextral fault, and, to the east, by a NNE-SSW sinistral fault (Fig. 5). This pattern indicates a Quaternary push of this hill southward. The $\mathrm{N} 30^{\circ} \mathrm{E}$ sinistral fault displaces Jbel Trhatt from Jbel Zalagh by
$5 \mathrm{~km}$. These faults also appear to be related to a north-south compression.

Jbel Kannoufa is formed by a monocline of Jurassic rocks gently dipping northward (Fig. 6a). However, it shows locally, in its southern front, parts of an anticlinal hinge and its steeply dipping southern limb. The Jurassic series of Jbel Kannoufa consists of thick Lower Liassic massive dolostones and limestones, and middle Liassic bioclastic and oolitic limestones (Faugères 1978; Bargach et al. 2004). Jbel Kannoufa is an inclined anticline clearly associated with longitudinal reverse faults (Bargach et al. 2004). This ridge has an east-west to ESE-WNW elongation and shows very high asymmetry, with a southward vergence. The southern limb is cut by WNW-ESE reverse faults (Fig. 6c) and longitudinal sinistral strike-slip faults (Fig. 6d) that affect the Miocene marls and

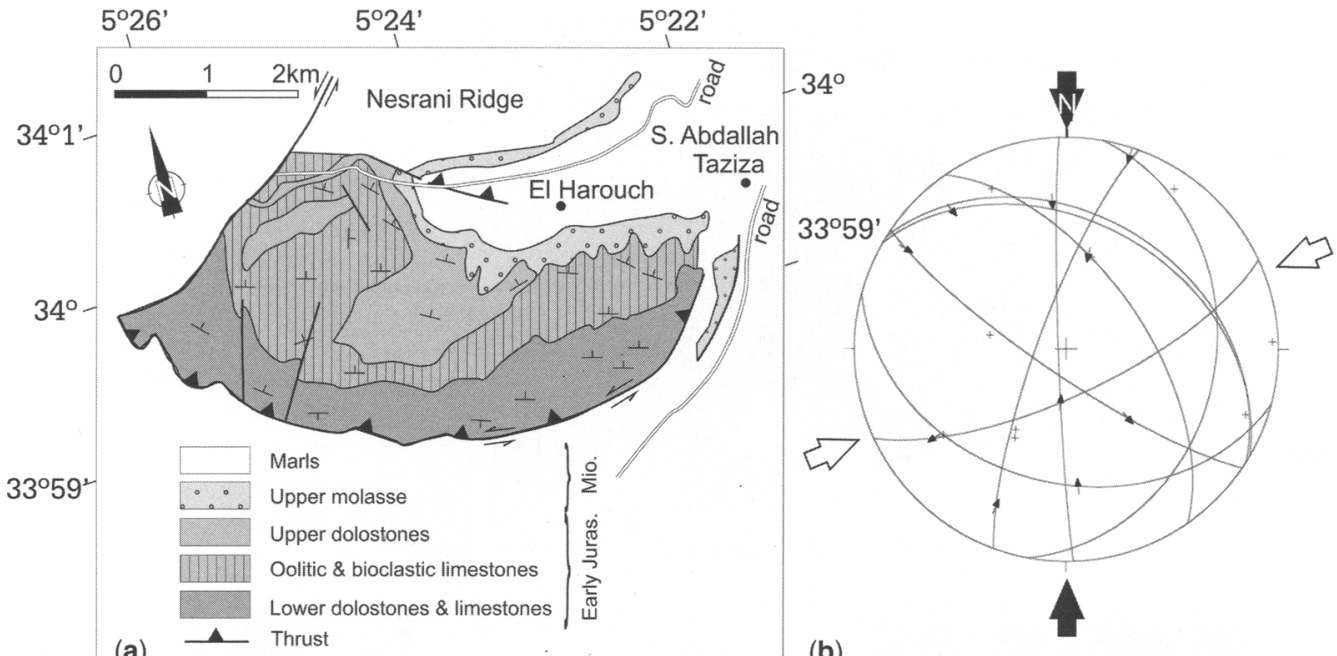

(a) $\leftrightarrows$ Thrust

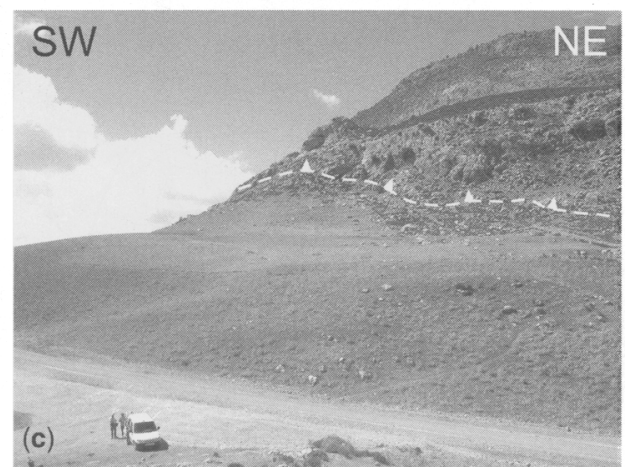

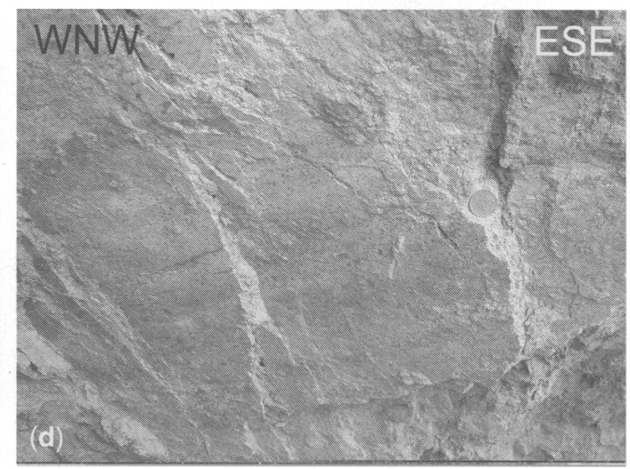

Fig. 6. Jbel Kannoufa. Geological map (a), stresses and measured microfaults (b), equal area projection, lower hemisphere. Black arrows, probable oldest compression; white arrows, probable youngest compression. (c) Field view of the frontal thrust. (d) Detailed view of a sinistral fault observed in the frontal part of the ridge. 
molasse, the Saïss Plio-Quaternary lacustrine formations and, locally, even late Quaternary terraces. The microstructures show north-south as well as east-west to ENE-WSW-oriented main compressions (Fig. 6b).

Jbel Zarhoun forms an important east-westoriented relief dominating the Meknes flat region. It is a faulted east-west elongated anticline, with a large northern low-dipping limb and a reduced southern flank, where frontal longitudinal faults are well developed (Fig. 7a). The Jurassic series consist of Lower and Middle Liassic limestones and dolostones, Toarcian-Aalenian marls and limestones, and Bajocian grey marls and coarse sandstones. The Jurassic series is covered by middle Miocene molasses and Upper Miocene white marls. Jbel Zarhoun is overthrust to the north by the thrust sheets forming the Jbels Dhar Nsour and Fert El Bir, which are also formed by Jurassic to Miocene Prerif Ridge rocks.
Longitudinal frontal faults from the southern boundary of the Jbel Zarhoun Ridge, and displace the Jurassic formations onto the Upper Miocene marls and the lacustrine Plio-Quaternary rocks of the Saïss Basin. The east-west longitudinal faults are south-verging reverse faults, sometimes crosscut by high-angle sinistral strike-slip faults (Fig. 7). The main compressional stresses deduced from sinistral motions have an ENE-WSW trend.

The Bou Draa and Outita ridges are situated SE of Sidi Kacem, in the northwestern extremity of the Prerif Ridges, delimited by $\mathrm{N} 50-70^{\circ} \mathrm{E}$-oriented faults from the Neogene Gharb basin (Fig. 3). They are NE-SW NW-verging anticlines. The Jurassic series cropping out in these ridges consists of Toarcian-Aalenian marls, limestones and sands, overlain by Bajocian sandstones, clays and dolostones. This series is unconformably covered by Upper Miocene molasse and white marls (Faugères 1978). The $\mathrm{N} 50-70^{\circ} \mathrm{E}$ faults that form the northwestern
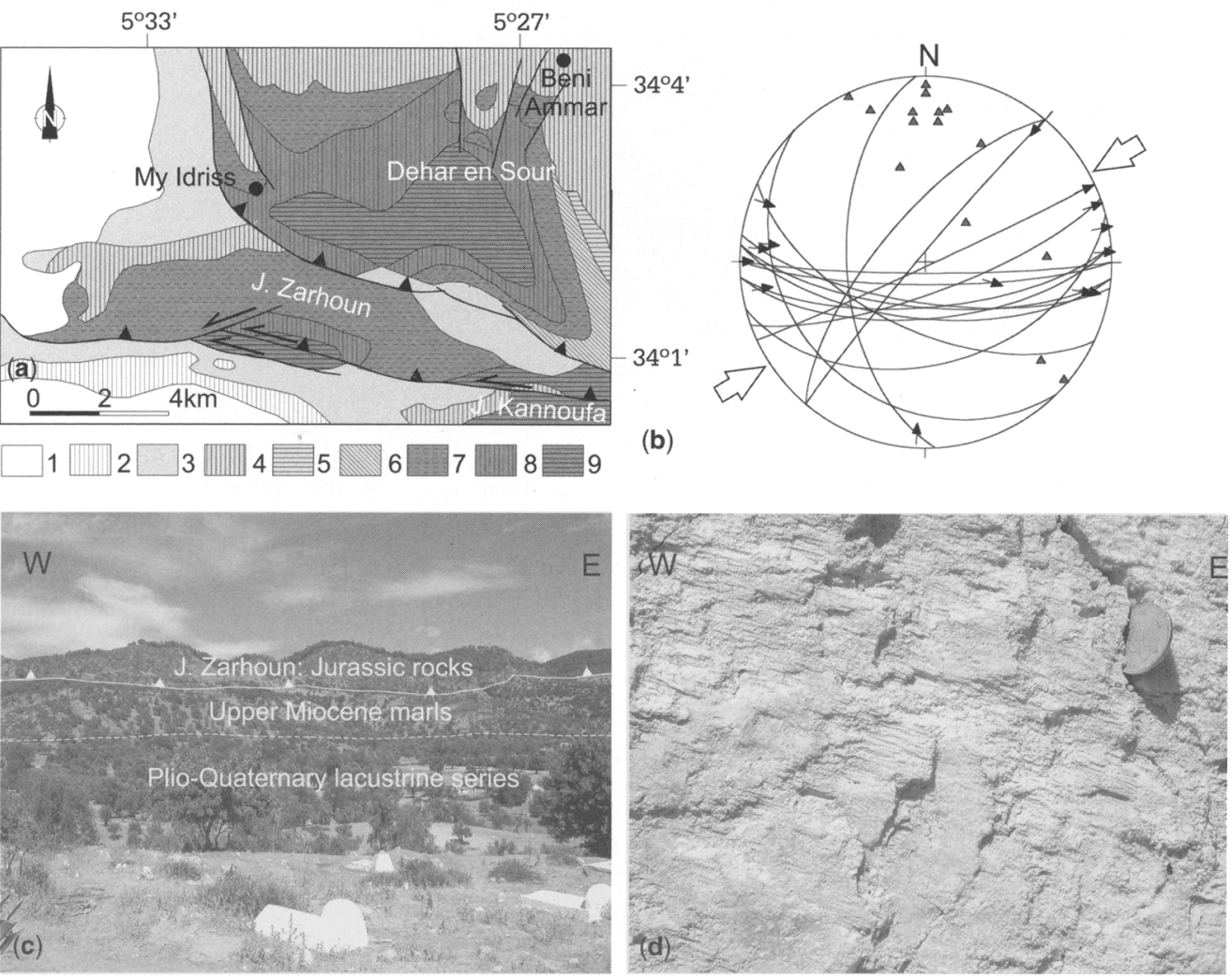

Fig. 7. Jbel Zarhoun. (a) Geological map. 1, Quaternary sediments; 2, Plio-Quaternary lacustrine sediments; 3, upper Miocene marls and conglomerates; 4, middle Miocene molasse; 5, Eocene marls; 6, Cretaceous marls; 7, Bajocian Zarhoun sandstones; 8, upper Liassic marls and limestones; 9, lower and middle Liassic limestones. (b) Stresses and measured microfaults, equal area projection, lower hemisphere. (c) Field view of the frontal thrust. (d) Detailed view of a sinistral fault observed in the frontal part of the ridge. 
boundary of the ridges affect the Jurassic and Miocene rocks, and locally the Plio-Quaternary lacustrine formations (conglomerates and limestones) of the Saiiss Basin. These are dextral strikeslip faults with a normal component when dipping NW, and a reverse component when dipping SE. This zone of shearing could be responsible for the rise and southward emplacement of the Prerif Ridges and for the $2000 \mathrm{~m}$ downthrow of the Gharb Basin. In seismic sections (Zizi 1996; Kenafi 2002), the fault zone of Bou Draa clearly appears as a system of very steep faults, Which first created a graben in which the Jurassic sediments deposited, and then underwent a tectonic inversion that produced the ridges. The Gharb Basin appears as a collapsed zone, its rear being compressed near the contact with the ridges of Bou Draa-Outita, and its centre and frontal part in extension (Flinch 1993; Flinch 1996). The microtectonic measurements taken along this zone point to two deformation stages: an ENE-WSW-oriented compression and a NNW-SSE-oriented extension (Fig. 8), which could be contemporaneous.

Along the South Rif gateway (Fig. 2), and especially in the northern border of the Saïss Basin, two outcrops have been studied: the Tensiftian conglomerates of Oued Sebou, and the lacustrine limestones of Draâ El Merga, respectively located $12 \mathrm{~km}$ to the ESE and $20 \mathrm{~km}$ WSW of Fez (Fig. 3). On the southern side of Oued Sebou (UTM, $x=555.3 \mathrm{~km} ; y=381.6 \mathrm{~km}$ ) a fluvial conglomeratic formation of Quaternary (Tensiftian) age crops out (Gourari 2001), overthrust by

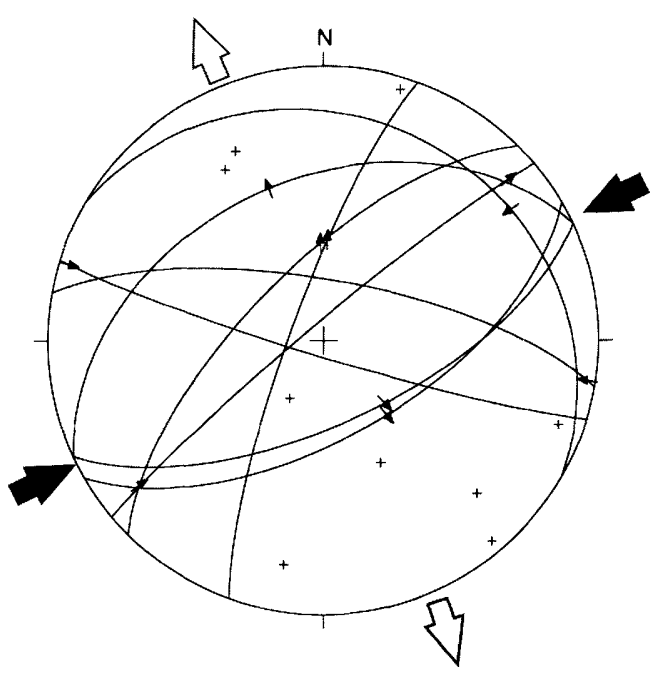

Fig. 8. Measured microfaults and stresses in Bou DraâOutita ridges, equal area projection, lower hemisphere. Black and white arrows indicate two stress phases. middle Miocene grey marls of the Saïss Basin. The reverse fault shows an east-west-oriented surface of several hundreds of metres, dipping $50^{\circ}$ north, and yielding striae oriented $\mathrm{N} 150-160^{\circ} \mathrm{E}$ with a dextral component. The vertical displacement of this fault cannot be determined precisely, as the base of the Quaternary formation is not visible, but it is at least $20 \mathrm{~m}$. This reverse fault indicates a NNW-SSE shortening.

The region of Draâ El Merga is characterized by $\mathrm{N} 70-90^{\circ} \mathrm{E}$-oriented areas of high relief where the Plio-Quaternary limestones of the Saïss lacustrine formation crop out. Ahmamou \& Chalouan (1988) described $\mathrm{N} 120-150^{\circ} \mathrm{E}$ kilometre sized en echelon folds, which are located in a N70$90^{\circ} \mathrm{E}$ narrow strip associated with sinistral faults and were reactivated during the Quaternary by a NNE-SSW regional shortening. This fault zone is also indicated by the seismic profiles (Fig. 9) that cross this region (Zizi 1996), which show two subparallel fault planes delimiting a shear zone in which the shallowest formations (PlioQuaternary lacustrine rocks) appear in a very open anticline. In its NE extremity, this fault seems to affect shallower levels up to the Tertiary cover.

\section{Meseta-Middle Atlas foreland}

The recent Plio-Quaternary compressive deformations have also been studied in the foreland, along the Middle Atlas and the Meseta. Sefrou (Fig. 3) is located in the northern extremity of the tabular Middle Atlas, where the subhorizontal Lower Liassic dolostones and limestones are covered by unconformable Plio-Quaternary lacustrine formations of the Saiss Basin or by the Quaternary fluvial or travertine formations (Charrière 1990; Gourari 2001; Ahmamou 2002; Hinaje 2004). The conglomerates and the lacustrine limestones of the Saïs Basin that crop out north of Sefrou, along the main road to Fez, are affected by east-west to NW-SE very open folds, indicating a north-south to NE-SW regional shortening.

In the Moroccan Meseta, near Casablanca, the Palaeozoic series is covered by Quaternary marine terraces and aeolian deposits. Six Quaternary marine terraces (Akil 1990; Chabli et al. 2003) and several aeolain deposits crop out in the quarries of Brahma and Mjeddba (Figs 3 and 10). These deposits, of early Quaternary (Messaoudien) and mid-Quaternary (Maarifien and Anfatien) ages, are affected by $\mathrm{N} 90-110^{\circ} \mathrm{E}$ sinistral and north-south dextral strike-slip faults. The states of stress calculated from these faults indicate NNE-SSW, NE-SW and east-west compressive deformations (Fig. 10). 

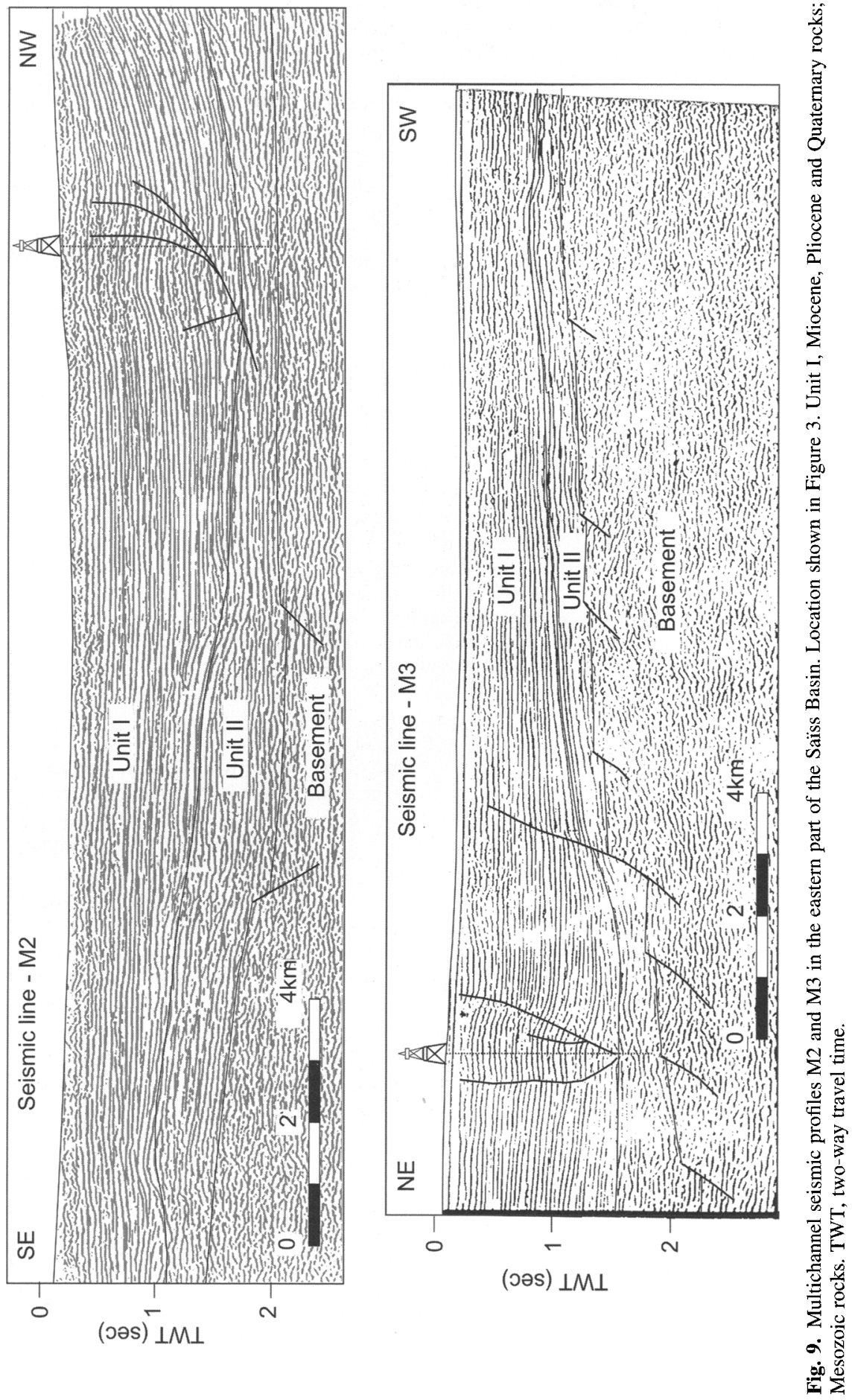

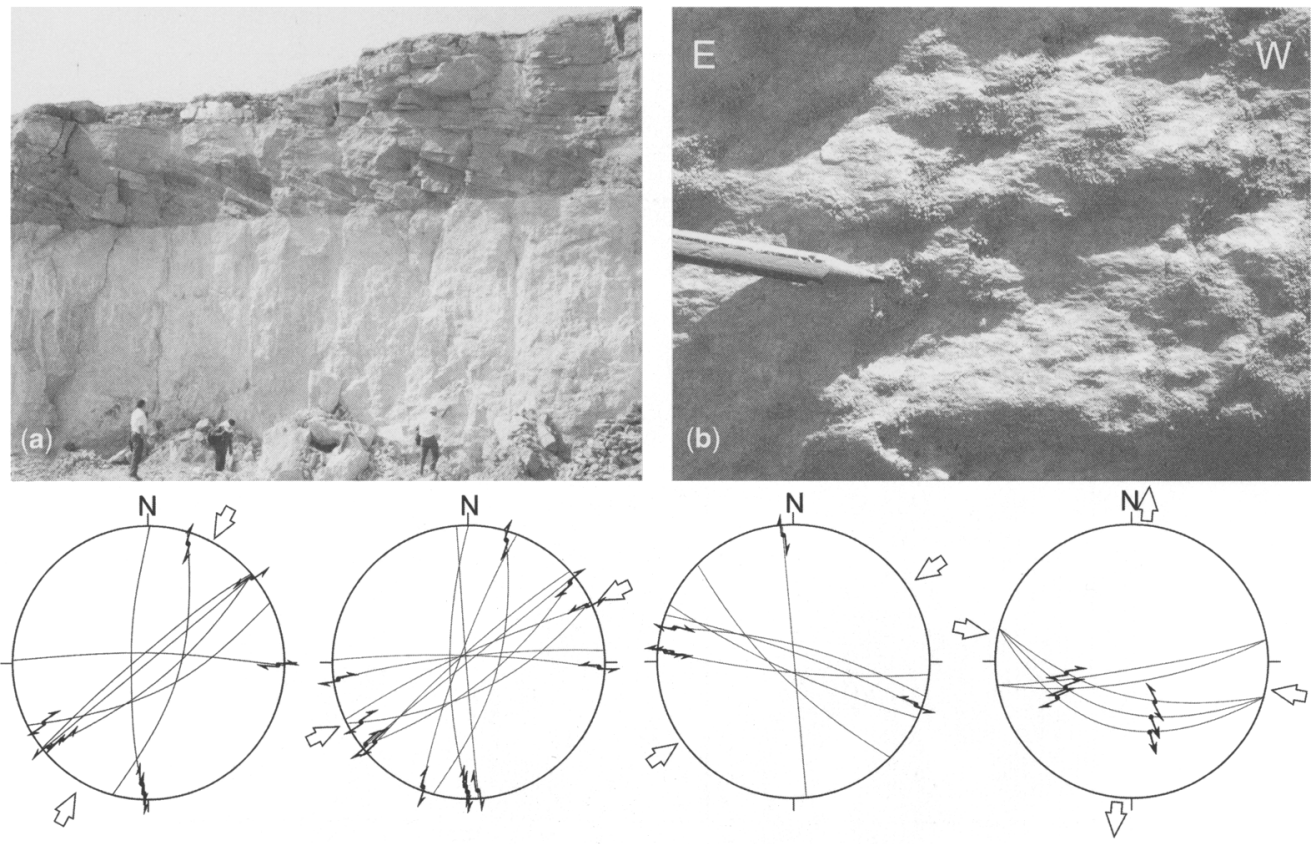

(c)

Fig. 10. Recent deformations in the Casablanca region. (a) Field view of the Quaternary marine and aeolian deposits affected by brittle deformations. (b) Detailed view of a sinistral fault. (c) Stresses and measured microfaults, equal area projection, lower hemisphere in different sectors of the Brahma and Mjeddba quarries in the lower and middle Quaternary sediments.

\section{Main faults in the Rif Cordillera}

The Rif mountain front can be regarded as a key area for understanding the evolution of the recent deformations related to the relative motion of the Eurasian, African and Alboran Domains. The results of our study indicate that this boundary zone, formed by the External Rif, the Prerif Ridges and the northern part of Meseta and Middle Atlas forelands, has undergone either simultaneous or successive north-south; NE-SW- and even east-west-trending shortenings (Fig. 11). The deformations of this boundary zone certainly resulted from a push of the Rif not only towards the south, but also towards the SW or even the west. These data cannot be considered in a single regional stress field, and for their adequate interpretation it

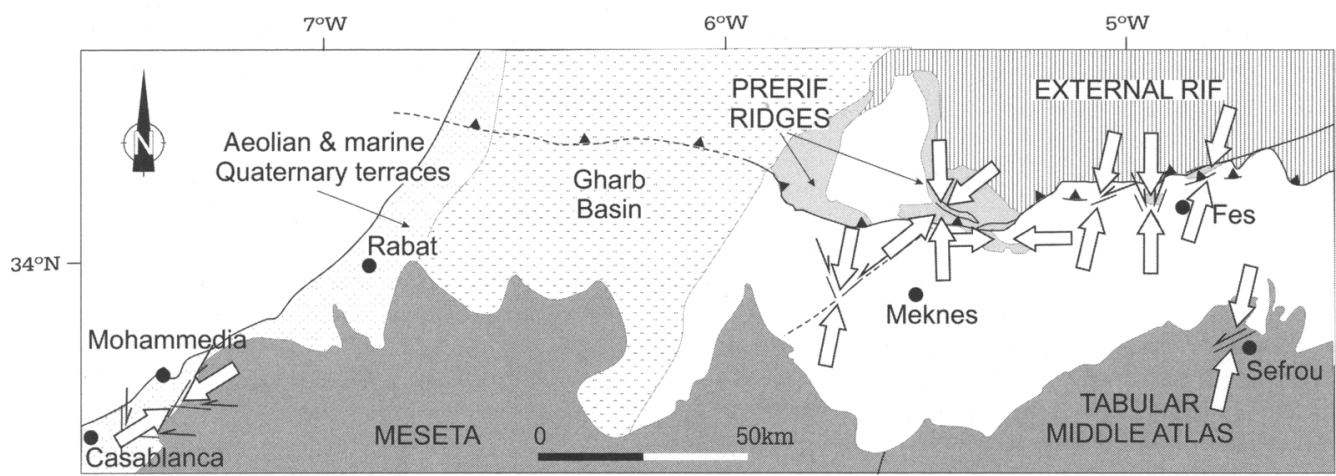

Fig. 11. Orientation of compressional stresses determined from the study of Quaternary structures in the Rif front and its Meseta-Middle Atlas foreland. 


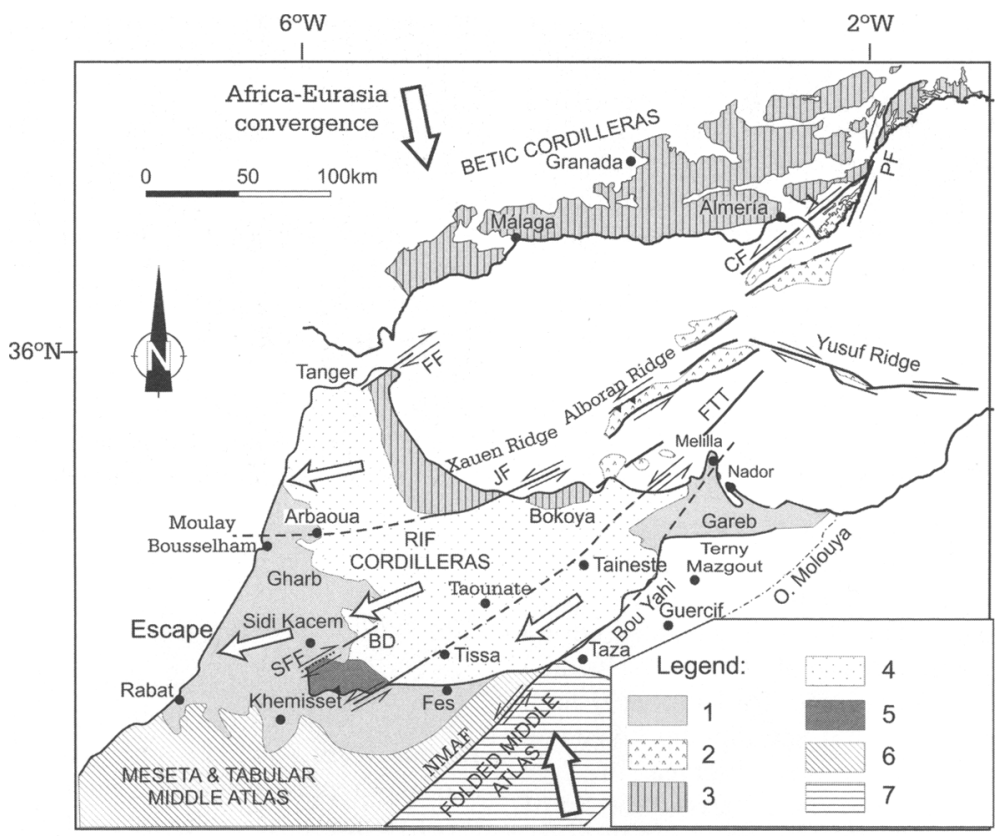

Fig. 12. Tectonic model of wedge escape in the Rif Cordillera. 1, Neogene and Quaternary basins; 2, Neogene volcanic rocks; 3, internal zones. 4, flysch nappes and External Rif; 5, Prerif ridges; 6, Meseta and Tabular Middle Atlas; 7, folded Middle Atlas. BD, Bou Draa fault; CF, Carboneras fault; FF, Fahies fault; FTT, Fez-Tissa-Taineste fault; JF, Jebha fault; NMAF, North-Middle Atlas fault; PF, Palomares fault; SFF, Sidi Fili-Bou Draa fault.

is necessary to take into account the features of the main crustal faults: those crossing the Rif chain and the Meseta-Middle Atlas Forelands (Fig. 12).

\section{The North-Middle Atlas fault zone}

The NE-SW-oriented North-Middle Atlas fault (NMAF) was defined by Colo (1961) as a major fault zone separating two different palaeogeographical domains: the tabular and the folded Middle Atlas (Figs 2 and 12). This fault zone, about $200 \mathrm{~km}$ long, develops between Taza to the north and the High Moulouya to the south. It is an old fault, which was active during the Liassic Atlas rifting and inherited from Variscan NE-SW structures (Laville \& Piqué 1991). This fault shows a sinistral transpressional activity during the pre-Miocene structuring of the Middle Atlas (Robillard 1978, 1979; Charrière 1990). It was also active up to the Plio-Quatemary, as it deforms and tilts the Pliocene and Villafranchian formations (Martin 1981) and determines and deforms the volcanic Quaternary lava flows (Thomas \& Fedan 1988), as also shown by palaeomagnetic studies (El Azzab \& El Wartiti 1988). Harmand \& Moukadiri (1986) suggested a model involving a sinistral motion of the NMAF during the Quaternary, related to the volcanic eruptions that exploited $\mathrm{N} 170^{\circ}$ E-oriented tension cracks. This fault has been described by some workers as a very important basement fault, continuing to Agadir in the south (Jacobshagen 1992), and it could be the source of the geothermal anomaly observed along this direction (Bahi et al. 1983). Bernini et al. (2000) associated this fault with a lineament that bounds and advances the Prerif with respect to the Middle Atlas in the Guercif Neogene basin and, according to Piqué et al. (1998), this fault zone behaved during the Neogene-Pleistocene period like a lithospheric mega-shear zone. In the Rif 1:500 000 geological map, the eastern boundary of the Rif, north of Taza, seems to coincide perfectly with the prolongation of the NMAF, which would therefore represent a sinistral lateral ramp of the Rif. The sinistral shift of the Rif front may be a consequence of the activity of this fault. Moreover, in the Terni-Mazgout area, the continuation of the Middle Atlas to the north of the Guercif Basin, as well as in the Gareb Massif, situated south of Nador, Hervouët (1985) pointed out north-south (N170-20 ${ }^{\circ}$ )- and $\mathrm{NE}-\mathrm{SW}\left(\mathrm{N} 40^{\circ} \mathrm{E}\right)$-oriented sinistral faults that affect the Plio-Quaternary lacustrine formations (Hamel 1971) and the Quaternary basalts aged 1.7-1.5 Ma, according to Cantagrel \& Harmand (1984) and Harmand \& Cantagrel (1984). The continuation 
of this fault into the Alboran Sea north of Melilla is not well constrained, although Andeweg \& Cloetingh (2001) proposed that it continues towards the Carboneras and Palomares faults in the east of the Betic Cordilleras, and forms the trans-Alboran Fault. However, the Alboran and Yussuf ridges, oriented $\mathrm{N} 60^{\circ} \mathrm{E}$ and $\mathrm{N} 100^{\circ} \mathrm{E}$, interrupt its continuity (Fig. 12). This fault zone may also be considered as an active fault, as recent earthquakes in Nador in November and December 2004 reached magnitudes near five.

\section{The Fez-Tissa-Taineste fault zone}

The Fez-Tissa-Taïneste fault zone (FTT) crops out between $\mathrm{Fez}$ and Taineste, along the FezTissa-Taounate road, and may extend as far as the Nekkor fault. This fault is emphasized by slices and tectonic horses of Triassic salts and gypsum, develops steep N50-70 E-oriented fault planes, and shows sinistral and dip-slip kinematic indicators. Fault planes are observed in Late Miocene formations (Tortonian marls of the Prerif Nappe and the middle Pliocene sands of Redom). The fault could be responsible for the $15 \mathrm{~km}$ sinistral displacement of the Prerif front west of Fez, of the overlying Ouezzane thrust sheet, and of the northern limit of the south Rif corridor (Fig. 12). This fault is offset by about $5 \mathrm{~km}$ in the northern prolongation of the $\mathrm{N} 20-40^{\circ} \mathrm{E}$ probable sinistral fault zone that displaces Jbel Zalagh and Jbel Trhatt (Fig. 3). The FTT fault could be relayed southward by other sinistral faults of parallel direction, which appear in the Saïss Basin or are hidden under the lacustrine formations. Among these, the Draa El Marga fault, oriented $\mathrm{N} 70^{\circ} \mathrm{E}$ (Fig. 9), which passes between Jbel Trhatt and Moulay Yakoub, has been described by Ahmamou \& Chalouan (1988).

Morel (1988) extended this fault zone toward the SW as far as Meknes and toward the NE to the Oued Kert (the Meknès-Fez-Kert fault), with its end located west of Nador. According to Morel, the fault bounds the eastern metamorphic Mesorif (Temsamane unit) to the east.

\section{The Bou Draa-Sidi Fili fault zone}

The Sidi Fili fault is buried under the Neogene and Quaternary sediments of the Saïs-Gharb Basins, but can be observed on the seismic sections or inferred from boreholes (Feinberg 1986). This fault zone is oriented NE-SW, with a SE dip, and was active as a normal fault during the Triassic-Jurassic rifting. During the Tertiary compression, it was reactivated as a reverse fault, contributing to the development of the Prerif
Ridges, mainly the western ridges of Bou DraaOutita (Zizi 1996; Kenafi 2002).

The NE-SW dextral Bou Draa fault zone (BD), located a few kilometres east of Sidi Kacem and delimiting the western border of the Bou Draa ridge, is in continuity with the Sidi Fili fault zone (Fig. 12), which has led some researchers to relate them. These faults were active together, as a dextral lateral ramp, during the TortonianMessinian southwestward emplacement of the western Prerif Ridges. The most recent rocks affected by these faults are of Messinian age, but a dextral Plio-Quaternary reactivation is feasible, as the Plio-Quaternary lacustrine formations are tilted or overthrust at the front of the western ridges (Kefs, Kannoufa and Zarhoun jbels).

\section{The Jebha fault zone}

The $\mathrm{N} 70^{\circ} \mathrm{E}$-oriented Jebha fault zone (JF) forms the southern border of the northwestern internal Rifian Domain (Figs 2 and 12). It has a sinistral component and may represent a lateral ramp during the westward progression of the internal domain after the early Burdigalian (Olivier 1981). The structures of the Internal Rif (Ghomarides, Sebtides and Dorsal complexes) are interrupted and deformed along this fault zone. The minimum sinistral displacement of the fault zone is estimated at $50 \mathrm{~km}$, taking into account the displacement of the Bokoya massif (Fig. 12). Seismic reflection profiles indicate an eastern continuation of this fault zone in the Alboran Sea, with the same orientation. It bounds the ridges of Xauen and Alboran, was reactivated as reverse (Bourgois et al. 1992; Comas et al. 1992, 1999) and sinistral faults with reverse vertical components (Chalouan et al. 1997), and affects Pliocene and even Quaternary formations (Chalouan et al. 1997).

The continuation of the Jebha fault toward the west is not very obvious. Several workers have assigned an important palaeogeographical role to this fault in the External Rif (Morley 1987, 1992; Tejera de León 1993, 1997), whereas others have pointed out deformations of the Tertiary outcrops of the External Rif (Morel 1988; Ben Yaïch 1991; Zakir 2004). Morel (1988) mapped east-west folds affecting the Early Pliocene formations in the westernmost prolongation of this fault, in the area of Moulay Bousselham (Fig. 12). On the other hand, in the region of Arbaoua, we observed $\mathrm{N} 110-160^{\circ} \mathrm{E}$ reverse faults affecting the Villafranchian continental conglomerates that may be related to the prologation of the Jebha fault (Figs 2 and 12). The gravimetric map likewise suggests the continuity of this fault in the External Rif (Morley 1987). This fault zone was probably active as sinistral, but the Palaeozoic, Mesozoic and Cenozoic 
(Eocene to early Miocene) formations of the Ghomarides-Sebtides are also affected by $\mathrm{N} 70-90^{\circ} \mathrm{E}$ dextral wrench faults (Benmakhlouf et al. 2005).

\section{The Fahiès fault zone}

This fault zone, first described by Kornprobst (1974), is a NE-SW to ENE-WSW fault that extends $15 \mathrm{~km}$, bounding the Internal Rif to the north (Fig. 12). It has a main dextral displacement and crosscuts the north-south-oriented structures of the Internal Rif, producing their clockwise rotation from $\mathrm{N} 170^{\circ} \mathrm{E}$ to $\mathrm{N} 20-30^{\circ} \mathrm{E}$. The Predorsalian thrust sheet and the other flysch deposits (Tisirène and Beni Ider) are also truncated by this fault. According to Ben Yaïch (1981), the dextral slip of this fault zone was active after the flysch emplacement. In the Internal Rif, Kornprobst (1974) and Zaghloul (1994) have indicated that this dextral fault affected the already emplaced Ghomarides and Dorsal complexes, and the Sebtide units, which show an Aquitanian-Burdigalian (19-25 Ma) metamorphism.

\section{Discussion}

The new data presented in this paper mainly contribute to highlight the Plio-Quaternary evolution of the frontal part of the Rif and its foreland. These data are integrated into the evolution of the whole Rif Cordillera (Chalouan et al. 2001, 2003; Michard et al. 2002; Chalouan \& Michard 2004).

East-west to NE-SW major sinistral fault zones, well developed in the central and eastern regions, deform the Rif Cordillera, and in some cases reach the frontal part. These faults have been active at least from the Early Miocene (Jebha fault) to the Messinian-Pliocene (Olivier 1981; Ahmamou \& Chalouan 1987; Morel 1988; Bargach et al. 2004). Moderate activity of several faults has continued to the Plio-Quaternary (Jebha fault, Morel 1988; Chalouan et al. 1997), and other new fault zones have developed, such as the Fez-Tissa-Taïneste and Sidi Fili-Bou Draâ fault zones. Seismic data indicate that the latter two also affect the basement (Fig. 9; Zizi 1996). These crustal faults determined the southwestward displacement of the Prerif Ridges. The FezTissa-Taïneste fault could also be a crustal fault, characterized by horses and thrust sheets of deformed Triassic marly and evaporitic rocks. Its southwestern part is recognized in seismic profiles (Benmakhlouf 2001). This fault may be responsible for the development of the $\mathrm{N} 120^{\circ} \mathrm{E}$ en echelon folds observed in the sedimentary cover in the Draâ El Merga area (Fig. 3, Ahmamou \& Chalouan 1988).
The major fault zones affecting the Rif Cordillera have orientations between $\mathrm{N} 45^{\circ} \mathrm{E}$ and $\mathrm{N} 70^{\circ} \mathrm{E}$. The $\mathrm{NE}-\mathrm{SW}$ fault zones are located in the eastern Rif, whereas the ENE-WSW ones are mainly located in the northern and western regions, with a progressive change in trend between these two extreme orientations. The fault zones recognized in the Rif Cordillera (e.g. Sidi Fili fault, Morel 1988; Zizi 1996) extend southwestward beneath the Saiiss Basin and the western Meseta. Other parallel faults can be interpreted from the seismic reflection profiles in the northern front of the Prerif Ridges and in the Gharb Basin (Flinch 1993; Zouhri et al. 2002), possibly representing deep faults formed during the Variscan orogenesis.

The eastern boundary of the Rif Cordillera is a $\mathrm{N} 40^{\circ} \mathrm{E}$-trending contact with the foreland (represented by the Neogene Guercif Basin, and the front of Jurassic and Palaeozoic rocks of BouYahi-Terni-Mazgout and Gareb massif; Fig. 12). This limit is located in the continuation of the North-Middle Atlas fault zone. The mainly sinistral transcurrent regime of these major fault zones during the Quaternary is supported by several studies (Charrière 1990; Charroud 1990; Andeweg \& Cloetingh 2001); Andeweg \& Cloetingh proposed that the North-Middle Atlas fault zone extends into the Rif foreland Bou Yahi fault zone and to the sinistral faults in the Betic Cordillera. Those workers indicated that during the Plio-Quaternary, the central and western Betic Cordilleras, the Alboran Sea, the Rif (Fig. 1), the Moroccan Meseta and the Middle Atlas (Fig. 2) were all displaced southwestward with respect to the surrounding Atlas, high plateaux, eastern Alboran Sea and eastern Betic Cordilleras (Sanz de Galdeano 1990a,b; Jacobshagen 1992).

Taking into account the field data presented in this paper and the previous studies on the region, it is considered that the transcurrent and thrustrelated displacements along large fault zones determined the tectonic evolution of the Rif Cordillera during the Miocene and the Quaternary. The main fault zones, oriented ENE-WSW (e.g. Jebha) in the northwestern Rif, and NE-SW in the SE (e.g. Fez-Tissa-Taïneste, and North-Middle Atlas), generally have a sinistral strike-slip motion, leading to the southwestward displacement of the tectonic units. Whereas towards the internal zone, in the northern part of the Rif, these major faults probably affect the whole crust, towards the mountain front, most of the faults affect only the detached cover on a Variscan basement and are related to a thin-skin tectonics. In most cases, there are not enough geophysical data to study in detail the prolongation at depth of the faults.

However, some of the main fault zones may affect the whole Rif Cordillera and foreland crust. 
The Jebha fault has been interpreted as a lateral ramp (Andrieux et al. 1971) of the Internal Rif, but geological and gravimetric (Morley 1987) studies suggest that this fault continues towards the WSW into the External Rif and the foreland, and may be considered a Variscan-Atlas crustal fault (Menvielle \& Le Mouël 1985). This fault separates a northern block with a relatively thin continental crust from the continental crust with normal thickness of the African margin (Van Den Bosch 1981; Morley 1987; Tejera de León 1997; Chalouan et al. 2001). On the Atlantic margin, this fault coincides with a zone of transition between oceanic crust to the north and continental crust to the south. Several workers (Morley 1987; Ben Yaïch 1991; Tejera de León 1997; Zakir et al. 2004) have suggested that this fault affects the crust and would have both influenced sedimentation and provoked deformations from the late Mesozoic to the Miocene, or even later, during the Alpine deformations of the Rif. Morel (1988) related the Plio-Quaternary deformations affecting the region of Moulay Bousselham and Arbaoua (Fig. 12) to this fault. The North-Middle Atlas fault extends southward to the Moroccan Atlantic coast and is considered to be a Variscan crustal fault (Bahi et al. 1983; Charrière 1990; Jacobshagen 1992; Bernini et al. 2000) reactivated during the Mesozoic rifting and the Tertiary-Quaternary north-south compressions. These two trans-Rif crustal faults extend also northeastward to the Alboran Sea and are associated with the main deformations in the Alboran Ridge, where Plio-Quaternary sediments are affected by folds and east-west thrust faults (Tesson et al. 1987; Maldonado et al. 1992; Chalouan et al. 1997, 2001; Comas et al. 1999).

The shortening caused by the Eurasia-Africa convergence was accommodated by deformation in the Alboran Sea and in the External Rif, represented by transfer and reverse faults in the Mesozoic and Cenozoic cover detached along the Triassic evaporite and clay levels (Zizi 1996; Samaka et al. 1997), and by the southwestward displacement of thick crustal wedges along deep faults (such as the Jebha fault and NMAF) affecting the central-eastern Rif and Moroccan Meseta.

According to Platt et al. (2003), the Alpine late Miocene folds and thrusts of the External Rif were initially $\mathrm{N} 150^{\circ} \mathrm{E}$-oriented in the central and eastern Rif, and became east-west-oriented after undergoing an anti-clockwise rotation of up to $55^{\circ}$, which is more intense near the Jebha fault. This could be due to the southwestward displacement of the thick crustal wedge bounded by the Jebha fault and NMAF.

The first stages of wedge escape probably occurred in the Rif Cordillera between the early Miocene and the Pliocene, as a result of the activity of the Jebha and Nekor faults. The activity of these structures allowed the development of the central Rif arc, located in the Mesorif and also in the post-thrust basins of Taounate, with a preferred NW-SE orientation, but with curved fold axes (Morel 1988; Samaka et al. 1997; Samaka 1999). During the final stages of this southwestward escape, the sinistral faults of Sidi Fili-Bou Draâ, Fez-Tissa-Taïneste, and probably the NorthMiddle Atlas-Melilla fault zone (Jacobshagen 1992; Bernini et al. 2000; Sani et al. 2000; Andeweg \& Cloetingh 2001), would have been the most active ones, relaying the previous faults. This period produced the southwestward expulsion of the Prerif Ridges, related to the development of the two tectonic arcs, the displacement of the Prerif Nappe and its emplacement in the GharbMaamoura Basin. The southwestward expulsion of the Rif is partially accommodated by the thrusts located at the front of several Prerif Ridges (Jbels Kannoufa and Zarhoun), or by blind thrusts related to south-vergent folds (e.g. Jbel Trhatt). In front of these ridges, north-south, NE-SW and even ENE-WSW compressional stresses have been determined from mesostructural sites of measurement.

The few $\mathrm{N} 70-90^{\circ} \mathrm{E}$ dextral fault planes observed along the Jebha fault zone are an indication supporting that this large fault zone was not only active with a sinistral regime, as a result of the fault position in the centre of the Rif. As a sinistral fault, it allows the escape of the northern Rif (north of the fault trace), and as a dextral fault it permits the escape of the central-eastern Rif (the zone located between the Jebha fault and the North-Middle Atlas fault).

These deformations affect recent sedimentary rocks (of early to mid-Quaternary age: Tansiftian to Maarifian), located mainly in the Rif front and in its western part, indicating that these areas continue to be tectonically active. In addition, this region shows seismic activity, with earthquake focal mechanisms showing variable trends (NWSE, north-south and even NE-SW) of the horizontal pressure axes (Medina \& Cherkaoui 1992; Medina 1995).

This region also shows a positive heat flow anomaly, mainly along the Prerif Ridges (Rimi et al. 1998), which is most intense along the Nekor fault zone and the Prerif front. An alignment of thermal sources (Benmakhlouf 2001; Winckel 2002; Winckel et al. 2002) is observed along the Bou Draa fault. This setting is typical of regions with deep evaporitic diapirs or Variscan granite basement (Rimi et al. 1998), or with recent tectonic activity that has resulted in brecciated fault zones (Bahi et al. 1983; Ahmamou \& Chalouan 1988; Benmakhlouf 2001; Winckel et al. 2002). 
The development of the Rif mountain front is probably a consequence of the interaction of two distinct main tectonic processes: (1) the opening of the Algerian-Provençal basin in the Western Mediterranean, which contributed to the westward motion of the Alboran Domain (e.g. Boillot et al. 1984; Sanz de Galdeano 1990a,b) between the Eurasian and African plates; (2) the development of the first stages of the Betic-Rif Cordilleras tectonic arc. In addition, the recent NW-SE convergence between the Eurasian and African plates (De Mets et al. 1990) allows the southwestward escape of the Rif-Meseta tectonic wedge located between major crustal fault zones of the Rif Cordillera: the Jebha fault $\left(\mathrm{N} 70^{\circ} \mathrm{E}\right)$, and the Fez-TissaTaïneste $\left(\mathrm{N} 50^{\circ} \mathrm{E}\right)$ and North-Middle Atlas fault zones $\left(\mathrm{N} 50^{\circ} \mathrm{E}\right)$. Along with the major blocks, other tectonic wedges of smaller size were expelled southwestward in the same way. In the frontal part of the Rif Cordillera, this expulsion is favoured by the presence of the subsiding Gharb Basin, open towards the Atlantic, which continues to undergo compressional deformations in its eastern sector (Flinch 1993; Litto et al. 2001) and extension in the western areas.

This changing tectonic scenario supports an anticlockwise rotation of the trend of maximum compression. Whereas the development of the first structures related to the southwestward tectonic wedge expulsion is in agreement with the NESW trend of maximum compression, a progressive transition has finally allowed the predominance of the NNW-SSE compression related to the present-day plate convergence.

\section{Conclusions}

The Rif mountain front, and in particular the Prerif Ridges front, is characterized by recent and active south-vergent tectonic structures such as thrusts, reverse and strike-slip faults, and folds, which produce tilting and even overturning of the sedimentary sequences, sometimes to those of Pliocene and Quaternaryage. These structures allow us to determine NW-SE and north-south main trends, and local NE-SW and even east-west trends of compression. The compressional structures deform, locally, sequences up to the Middle Atlas and Quaternary sedimentary rocks of the Moroccan coastal Meseta.

In addition, the Rif Cordillera and the Saiss and Gharb Basins are deformed by $\mathrm{N} 40^{\circ} \mathrm{E}-\mathrm{N} 70^{\circ} \mathrm{E}$ transcurrent crustal fault zones that deform the basement. These major faults, which have been identified in outcrops and on seismic profiles, bound large crustal blocks and generally have a sinistral strike-slip component. Two major fault zones with trends of $\mathrm{N} 70^{\circ} \mathrm{E}$ (in the $\mathrm{NW}$ ) and $\mathrm{N} 40^{\circ} \mathrm{E}$ (in the $\mathrm{SE}$ ) have resulted in a large wedgeshaped block in the southwestern Rif Cordillera that may have escaped southwestward. This displacement of tectonic blocks may be the consequence of the combined activity of the NW-SE convergence of the Eurasian and African plates, and oceanic expansion in the Western Mediterranean during the development of the Algerian-Provençal Basin.

The lateral southwestward escape of the orogenic wedges bounded by transcurrent and thrust faults along the Rif front involved thin-skin tectonics, also indicated by the deformation in the borders of the Saïss and Gharb-Maamoura Basins surrounding the Rif front, the latter being open to the Atlantic. The westward motion continued to recent times, favoured by the activity of the crustal fault zone located between the Rif and the Atlas, and emphasized by the presence of thermal sources, high heat flow and seismic activity.

Although in some areas the NE-SW compressional palaeostresses related to the southwestward tectonic wedge expulsion predominate, in other regions (and in a transitional way) where the activity of this tectonic process is more moderate, the NNW-SSE compression related to the convergence of the Eurasian and African plates predominates. The frontal part of the Rif Cordillera is a key area for studying the variability of the deformations related to the NW-SE convergent Eurasian-African plate boundary, modified by the interaction of a complex set of tectonic elements between the major plates.

The comments of A. Michard and F. Medina have greatly improved the quality of this contribution. The research has been financed by collaborative Spanish-Moroccan projects of the Junta de Andalucía, the AECI and CICYT project BTE2003-01699.

\section{References}

Ahmamou, A. 2002. Evolution et dynamique sédimentaire des carbonates fluvio-lacustres plio-quaternaires dans le Saïs de Fès (Maroc). Thèse d'Etat, Université Mohammed V, Rabat.

Ahmamou, A. \& Chalouan, A. 1988. Distension synsédimentaire plio-quaternaire et rotation antihoraire des contraintes au Quaternaire ancien sur la bordure nord du bassin du Saïss (Maroc). Bulletin de l'Institut Scientifique, Rabat, 12, 19-26.

AïT BRAHIM, L. 1991. Tectonique cassante et états de contraintes récents au Nord du Maroc. Contribution à l'étude du risque sismotectonique. Thèse Doctorat d'Etat, Université Mohammed V, Rabat.

AKIL, M. 1990. Les dépôts quaternaires littoraux entre Casablanca et Cap Beddouza (Meseta côtière marocaine): études géomorphologiques et 
sédimentologiques. Thèse Doctorat d'Etat, Université Mohammed V, Rabat.

ANDEweg, B. \& Cloetingh, S. 2001. Evidence for an active sinistral shear zone in the western Alboran region. Terra Nova, 13, 44-50.

Andrieux, J., Fontboté, J. M. \& Mattauer, M. 1971. Sur un modèle explicatif de l'Arc de Gibraltar. Earth and Planetary Science Letters, 12, $191-198$.

BAhi, L., El Yamine, N. \& Risler, J. J. 1983. Linéaments géothermiques au Maroc. Comptes Rendus de l'Académie des Sciences, Série II, 296, $1087-$ 1092.

Bargach, K., Ruano, P., Chabli, A., et al. 2004. Recent tectonic deformations and stresses in the frontal part of the Rif Cordillera and the Saïs Basin (Fez and Rabat regions, Morocco). Pure and Applied Geophysics, 161, 521-540.

BenmakHLouf, M. 2001. Les sources thermales $d u$ Maroc septentrional: relation entre le thermalisme et la tectonique. Thèse Doctorat d'Etat, Université Mohammed V, Rabat.

Benmakhlouf, M., Galindo-Zaldívar, J., Chalouan, A., Sanz de Galdeano, C., Ahmamou, M. \& López-Garrido, A. C. 2005. Cinemática y paleoesfuerzos en la zona de falla transcurrente de Jebha-Chrafate (Rif septentrional, Marruecos), Geogaceta, 38, 71-74.

BEN YAÏCH, A. 1981. Etude géologique de la Dorsale calcaire entre Tlata Taghramt et Ben Youens (Haouz Rif, Maroc). Diplôme Etudes Supérieures Thèse, Université Mohammed V, Rabat.

BEN YAÏCH, A. 1991. Evolution tectono-sédimentaire $d u$ Rif externe centro-occidental (région de $M$ 'Sila et Ouezzane, Maroc): la marge africaine du jurassique au Crétacé; les bassins néogènes d'avant fosse. Thèse d'Etat, Université de Pau et des Pays de l'Adour.

Bernini, M., Boccaletti, M., Moratti, G. \& PAPANI, G. 2000. Structural development of the Taza-Guercif Basin as a constraint for the Middle Atlas Shear Zone tectonic evolution. Marine and Petroleum Geology, 18, 391-408.

Boillot, G., Montadert, L., Lemoine, M. \& Biju-Duval, B. 1984. Les Marges continentales actuelles et fossiles autour de la France. Masson, Paris.

Bourgois, J., Mauffret, A., Ammar, A. \& Demnati, A. 1992. Multichannel seismic data imaging of inversion tectonics of the Alboran ridge (Western Mediterranean Sea). Geo-Marine Letters, 12, 165-172.

Bouybaouene, M. L., Goffé, B. \& Michard, A. 1998. High-pressure granulites on top of the Beni Bousera Peridotite, Rif Belt Morocco: a record of an ancient thickened crust in the Alboran domain. Bulletin de la Société Géologique de France, 169, 153-162.

Cantagrel, J. M. \& Harmand, C. 1984. Le volcanisme récent du Moyen-Atlas (Maroc): chronologie $\mathrm{K} / \mathrm{Ar}$ et cadre géodynamique. 10ème Réunion Annuelle des Sciences de la Terre, Bordeaux, 115.

Chabli, A., Galindo-Zaldívar, J., Akil, M., et al. 2003. Nouvelles observations sédimentologiques, stratigraphiques et néotectoniques sur les formations plio-quaternaires de la région de Témara. Notes et Mémoires du Service Géologique du Maroc, 452, 293-300.

Chalouan, A. \& Michard, A. 2004. The Alpine Rif Belt (Morocco): a case of mountain building in a subduction-subduction-transform fault triple junction. Pure and Applied Geophysics, 161, 489-519.

Chalouan, A., Saji, R., Michard, A. \& Bally, A.W. 1997. Neogene tectonic evolution of the southwestern Alboran basin as inferred from seismic data of Morocco. AAPG Bulletin, $\mathbf{8 1}$ $1161-1184$

Chalouan, A., Galindo-Zaldívar, J., Bargach, K., ET AL. 2000. Deformaciones recientes en el frente de la Cordillera Rifeña (Prerif, Marruecos). Geogaceta, 29, 43-46.

Chalouan, A., Michard, A., Feinberg, H., MONTIGNY, R. \& SADDIQI, O. 2001. The Rif mountains building (Morocco): a new tectonic scenario. Bulletin de la société Geologique de France, 172(5), 603-616.

Chalouan, A., Michard, A., Feinberg, H., Montigny, R. \& SAdDiQl, O. 2003. L'édification de la chaine du Rif (Maroc) dans le cadre tectonique méditerranéen. Notes et Mémoires du Service géologique du Maroc, 447, 69-98.

ChARrière, A. 1990. Héritage hercynien et évolution géodynamique alpine d'une chaîne intracontinentale: le Moyen-Atlas au SE de Fès (Maroc). Thèse Doctorat d'Etat, Université de Toulouse.

Charroud, M. 1990. Evolution géodynamique de la partie sud-ouest du Moyen-Atlas durant le passage Jurassique-Crétacé, le Crétacé et le Paléogène: un exemple d'évolution intraplaque. Diplôme Etudes Supérieures Thèse, Université Mohammed V, Rabat.

Colo, G. 1961. Contribution à l'étude du Jurassique du Moyen Atlas septentrional (Maroc). Notes et Mémoires du Service Géologique du Maroc, 139.

Comas, M. C., Garcia-Dueñas, V \& Jurado, J. 1992. Neogene tectonic evolution of the Alboran Sea from MCS data. Geo-Marine Letters, 12, 157-164.

Comas, M. C., Platt, J. P., Soto, J. I. \& Watts, A. B. 1999. The origin and tectonic history of the Alboran basin: insights from ODP leg 161 results. In: Zahn, R., Comas, M. C. \& Klaus, A. (eds) Proceeding of the Ocean Drilling Program, Scientific Results, 161. Ocean Drilling Program, College station, TX, 555-580.

De Mets, C., Gordon, G. G., Argus, D. F. \& Stein, S. 1990. Current plate motions. Geophysical Journal International, 101, 425-478.

El AzzaB, D. \& El Wartiti, M. 1988. Paleomagnetism of Middle Atlas lavas (Morocco): recent rotations. Comptes Rendus de l'Académie des Sciences, Série IIA, 327(8), 509-512.

FAUGÈres, J. C. 1978. Les Rides sud rifaines; évolution sédimentaire et structurale d'un bassin atlantico-mésogène de la marge africaine. Thèse Doctorat d'Etat, Université de Bordeaux I. 
FeInBerG, H. 1986. Les séries tertiaires des zones externes du rif (Maroc); biostratigraphie, paléoécologie et aperçue tectonique. Notes et Mémoires du Service Géologique du Maroc, 315.

FLINCH, F. J. 1993. Tectonic evolution of the Gibraltar arc. $\mathrm{PhD}$ thesis, Rice University, Houston, TX.

FLINCH, F. J. 1996. Accretion and extensional collapse of the external western Rif (Northern Morocco). Mémoires du Muséum National de l' Histoire Naturelle de Paris, 170, 61-85.

Frizon de Lamotte, D., Saint Bezar, B., Bracène, R. \& MErcier, E. 2000. The two main steps of the Atlas building and geodynamics of the western Mediterranean. Tectonics, 19, 740-761.

García-Dueñas, V. \& Balanyá, J. C. 1986. Estructura y naturaleza del Arco de Gibraltar. Maleo Boletim Informativo da Sociedade Geológica de Portugal, 2, 23.

Goffé, B., Azañón, J. M., Bouybaouen, M. L. \& Jullien, M. 1997. Métamorphic cookeite in Alpine metapilites from Rif (northern Morocco) and Betic Chains (southern Spain). European Journal of Mineralogy, 6, 897-911.

GOURARI, L. 2001. Etude hydrochimique, morphologique, lithostratigraphique, sédimentologique et pétrographique des dépôts travertino-détritiques actuels et plio-quaternaires du bassin karstique de l'Oued Aggay (Causse de Sefrou, Maroc). Thèse Doctorat d'Etat, Université de Fès.

Hamel, СH. 1971. Carte géologique au 1/100 000 de Tistoutine. Notes et Mémoires du Service Géologique du Maroc, 167.

Harmand, C. \& Cantagrel, J. M. 1984. Le volcanisme alcalin tertiaire et quaternaire du MoyenAtlas (Maroc): chronologie $\mathrm{K} / \mathrm{Ar}$ et cadre géodynamique. Journal of African Earth Sciences, 2(1), 51-55.

Harmand, C. \& Moukadiri, A. 1986. Synchronisme entre tectonique compressive et volcanisme alcalin: exemple de la province quaternaire du Moyen-Atlas (Maroc). Bulletin de la Société Géologique de France, Série II, 8(4), 595-603.

Hervouët, Y. 1985. Géodynamique alpine (Triasactuel) de la marge septentrional de l'Afrique $d u$ Nord du bassin de Guercif (Maroc oriental). Thèse d'Etat, Université de Pau et des Pays de l'Adour.

HinAJE, S. 2004. Tectonique cassante et paléochamps de contraintes dans le Moyen Atlas et le Haut Atlas central (Midelt-Errachidia) depuis le Trias jusqu'à l'Actuel. Thèse Doctorat d'Etat, Université Mohammed V, Rabat.

JACOBSHAGEN, V. 1992. Major fracture zones of Morocco: the South Atlas and the Transalboran fault systems. Geologische Rundschau, 81, $185-197$

KENAFI, J. 2002. Evolution structurale méso-cénozoïque des Rides périfaines (Maroc): halocinèse, géométrie et reconstitution géodynamique. Apport de données de sismique réflexion et de forages pétroliers. Thèse de Doctorat, Université de Kénitra.

Kornprobst, J. 1974. Contribution à l'étude pétrographique et structurale de la zone interne du Rif
(Maroc septentrional). Notes et Mémoires du Service Géologique du Maroc, 251.

LAville, E. \& Piqué, A. 1991. La distension crustale atlantique et atlasique du Maroc au début du Mésozoïque: le rejeu des structures hercyniennes. Bulletin de la Société Géologique de France. 162, $1161-1171$

Litto, W., JaAïdi, E., Medina, F. \& Dakki, M. 2001. Seismic study of the structure of the northern margin of the Gharb basin (Morocco)-evidence for a late Miocene distension. Eclogae Geologicae Helvetica, 94, 63-74.

Maldonado, A., Campillo, A. C., Mauffret, A., Alonso, B., Woodside, J. \& Campos, J. 1992. Alboran Sea late Cenozoic tectonic and stratigraphic evolution. Geo-Marine Letters, 12 , $179-186$.

Martin, J. 1981. Le Moyen Atlas central, étude géomorphologique. Notes et Mémoires du Service Géologique du Maroc, Rabat, 258 and 258bis.

Medina, F. 1995. Present-day state of stress in Northern Morocco from focal mechanism analysis. Journal of Structural Geology, 17(7), 1035-1046.

Medina, F. \& Cherkaoui, T. E. 1992. Mécanismes au foyer des séismes du Maroc et des régions voisines (1959-1986). Journal of Structural Geology, 17, 1035-1046.

Menvielle, M. \& LE MouëL, J.-L. 1985. Existence d'une anomalie de conductivité dans le HautAtlas marocain et concentration des courants telluriques à l'échelle régionale. Bulletin de la Société Geéologique de France, 8(1), 553-558.

Michard, A., Chalouan, A., Feinberg, H., Goffé, B. \& Montigny, R. 2002. How does the Alpine belt end between Spain and Morocco? Bulletin de la Société Géologique de France, 173, 3-15.

Moratti, G., Piccardi, L., Vannucci, G., Belardinelli, M. E., Dahmani, M., Bendkik, A. \& Chenakeb, M. 2003. The 1755 'Meknes' earthquake (Morocco): field data and geodynamic implications. Joumal of Geodynamics, 36, 305-322.

Morel, J. L. 1988. Evolution récente de l'orogène rifain et de son avant-pays depuis la fin de la mise en place des nappes (Rif-Maroc). Geodiffusion Memoire, 4, Paris.

MORley, K. 1987. Origin of major cross element zone: Morocco Rif. Geology, 15, 761-764.

MorLEY, C. K. 1992. Notes on Neogene basin history of the Western Alboran Sea and its implications for the tectonic evolution of the Rif-Betic orogenic belt. Journal of African Earth Sciences, 14, 57-65.

Olivier, Ph. 1981. L'Accident de Jebha-Chrafate (Rif, Maroc). Revue de Géologie Dynamique et Géographie Physique, 22, 201-212.

Piqué, A., Ait Brahim, L., El Azzouzi, E., Maury, R. C., Bellon, H., Semroud, B. \& Laville, E. 1998. Le poinçon maghrébin: contraintes structurales et géochimiques. Comptes Rendus de l'Académie des Sciences, 326, 575-581.

Platt, J. P., Allerton, S., Kirker, A., Mandeville, C., Mayfield, A., Platzman, E. S. \& Rimi, A. 2003. The ultimate arc: differential displacement, oroclinal bending, and vertical 
axis rotation in the External Betic-Rif arc. Tectonics, 22, 1017, doi: 10.1029/2001TC001321.

Rimi, A, Chalouan, A. \& BaHI, L. 1998. Heat flow in the westernmost part of the Alpine Mediterranean system (the Rif, Morocco). Tectonophysics, 285, $135-146$.

Robillard, D. 1978. Etude structurale du Moyen Atlas septentrional au sud de Taza (Maroc). Thèse Doctorat zème cycle, Université de Lille.

RobILLARD, D. 1979. Tectonique synsédimentaire du Moyen Atlas septentrional au sud de Taza (Maroc). Bulletin de la Société Géologique de France, 7(4), 441-447.

RoYDEN, L. H. 1993. Evolution of retreating subduction boundaries formed during continental collision. Tectonics, 12, 629-638.

Ruano, P., Bargach, K., Galindo-Zaldívar, J., Chalouan, A. \& Ahmamou, M. 2006. Recent palaeostresses from striated pebbles related to fold development in a mountain front: the Prerif Ridges (Rif Cordillera, Morocco). In: MORATTI, G. \& Chalouan, A. (eds) Tectonics of the Western Mediterranean and North Africa. Geological Society, London, Special Publications, 262, 87-99.

SAMAKA, F. 1999. Apport de la géophysique (sismique réflexion) à l'étude de l'évolution sédimentologique, structurale et paléogéographique des bassins supra-nappes du Rif central. Thèse de Doctorat, Université Mohammed V, Rabat.

SAMAKA, F., BENYAICH, A., DAKKI, M., HÇAINE, M. \& BAlly, A. W. 1997. Origine et inversion des bassins miocènes supra-nappes du Rif central (Maroc). Etude de surfaces et de subsurface. Exemple des bassins de Taounate et de Tafrant. Geodinamica Acta, 10, 30-40.

SANI, F., ZIZI, M. \& BALly, A. W. 2000. The Neogene-Quaternary evolution of the Guercif Basin (Morocco) reconstructed from seismic line interpretation. Marine and Petroleum Geology, 17, 343-357.

SanZ DE Galdeano, C. 1990a. Geologic evolution of the Betic Cordilleras in the Western Mediterranean, Miocene to the present. Tectonophysics, 172, 107-119.

SANZ DE GaldeANO, C. 1990b. La prolongación hacia el sur de las fosas y desgarres del Norte y Centro de Europa: una propuesta de interpretación. Revista de la Sociedad Geologica de España, 3, 231-24I.

TEJERA DE LEón, J. 1993. Les bassins néogènes d'avant-pays du Rif externe occidental liés à la transformante Jebha-Arbaoua (Maroc). Thèse Doctorat d'Etat, Université de Pau et des Pays de l'Adour.

Tejera de León, J. 1997. Signification de la limite Jebha-Arbaoua (Maroc nord-occidental): une rampe latérale au dessus d'une discontinuité crustale héritée de la période de rifting. Journal of African Earth Sciences, 24, 455-472.

Tesson, M., Gensous, B. \& Labraïmi, M. 1987. Seismic analysis of the southern margin of the Alboran Sea. Journal of African Earth Sciences, 6, 813-821.

Thomas, G. \& Fedan, B. 1988. Activité de l'accident nord-moyen-atlasique au nord de Boulemane (Maroc). Au cours du Mio-Pliocène. 12ème Réunion Annuelle des Sciences de la Terre, Lille, 125.

VAN Den Bosch, J. W. H. 1981. Mémoire explicatif de la carte gravimétrique du Maroc (provinces du Nord) au 1/500000. Notes et Mémoires du Service Géologique, no. 234, 219.

WERnLI, R. 1988. Micropaléontologie du Néogène post nappes du Maroc septentrional et description systématique des foraminifères planctoniques. Notes et Mémoires du Service Géologique du Maroc, 331.

WinCKEL, A. 2002. Essai d'établissement d'une typologie de sources thermales par une approche hydrochimique, isotopique et tectonique. Exemple du Maroc. Thèse de Doctorat, Université Paris XI d'Orsay.

Winckel, A., Marlin, C., Dever, L., Morel, J. L., El Morabiti, K., Ben Makhlouf, M. \& Chalouan, A. 2002. Apport des isotopes stables dans l'estimation des altitudes de recharge de sources thermales du Maroc septentrional et oriental. Comptes Rendus Geosciences, 334, 469-474.

Zaghloul, M. N. 1994. Les unités Federico septentrionales (Rif interne, Maroc) inventaire des déformations et contexte géodynamique. Thèse, Diplôme Etudes Supérieures, Université Mohammed V, Rabat.

ZAKIR, A. 2004. Les bassins tertiaires d'avant-fosse du Rif externe nord-occidental: approche sédimentologique et structurale des séries turbiditiques de la région d'El Ksar El Kebir. Thèse de Doctorat, Université Mohammed V, Rabat.

Zakir, A. Chalouan, A. \& Feinberg, H. 2004. Plis de propagation et conséquences de leur rupture en domaine d'avant-chaîne, Rif nord-occidental, Maroc. Bulletin de la Société Géologique de France, 173, 3-15.

ZIZI, M. 1996. Triassic-Jurassic extensional systems and their Neogene reactivation in northeastern Morocco (the Prerifaines Ridges and Guercif basin). PhD thesis, Rice University, Houston, TX.

Zouhri, L., Lamouroux, C. \& Buret, C. 2002. La Mamora, charnière entre la Meseta et le Rif: son importance dans l'évolution géodynamique postpaléozoique du Maroc. Geodinamica Acta, 14, $361-372$. 